November 1989

\title{
Gamma and Beta Logging of Underground Sewer and Process Lines
}
M. J. Rangel
D. E. Martz
G. H. Langner, Jr.

DO NOT MICROFILM COVER

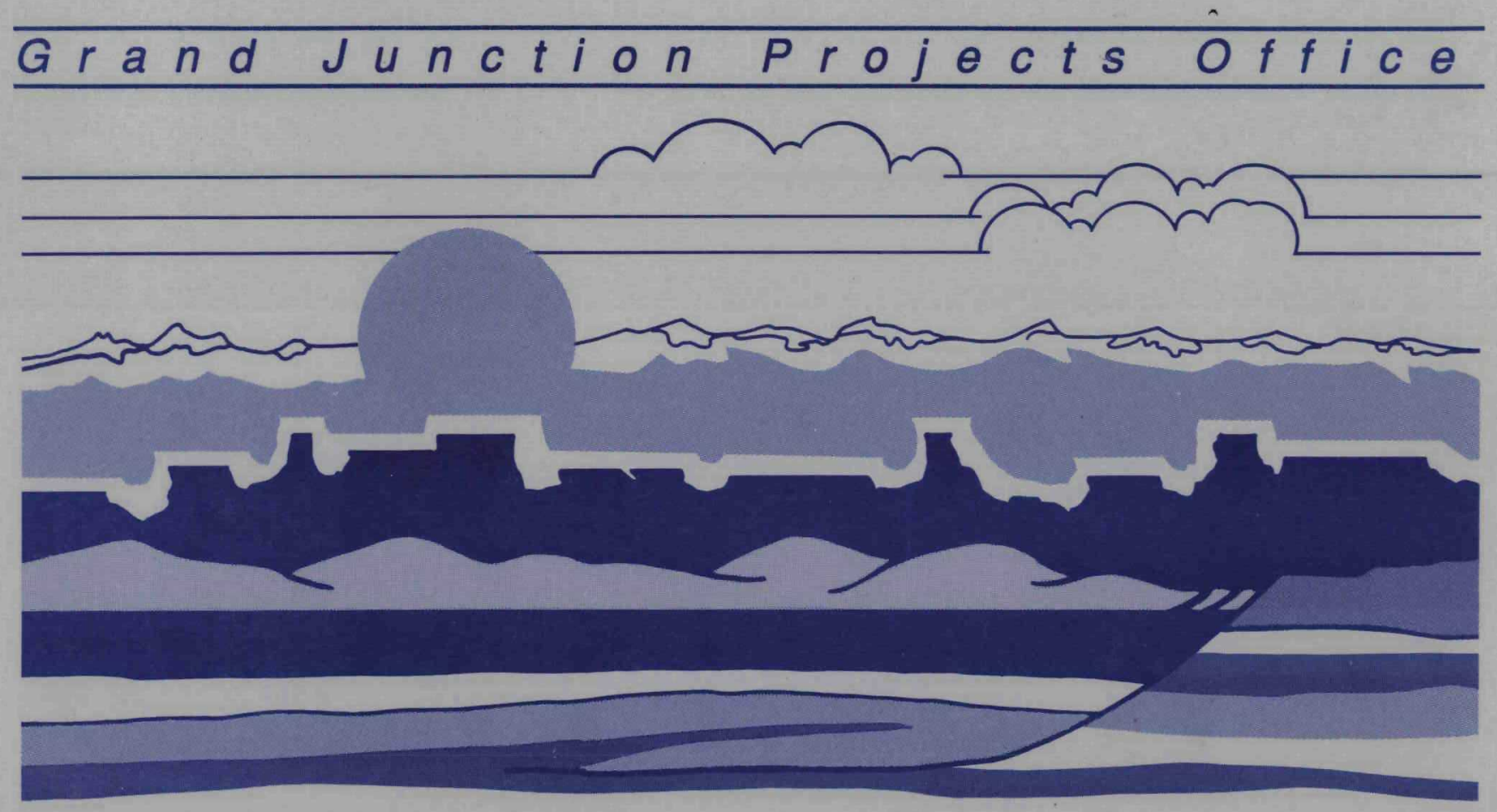


This report has been reproduced from the best available copy. Printed in the United States of America. Available from:

National Technical Information Service

U.S. Department of Commerce

5285 Port Royal Road

Springfield, VA 22161

NTIS price codes

Printed copy: A02

Microfiche copy: A01

\author{
Michael K. Tucker, Manager \\ Grand Junction Projects Office \\ Larry Ball, DOE Program Manager \\ Grand Junction Projects Office \\ John R. Duray, Program Manager \\ Mark Pearson, Project Manager \\ Technical Measurements Center
}

This report was prepared as an account of work sponsored by an agency of the United States Government. Neither the United States Government nor any agency thereot, nor any of their employees, makes any warranty, express or implied, or assumes any legal liability or responsibility for the accuracy, completeness, or usefulness of any information, apparatus, product, or process disclosed in this report, or represents that if use would not infringe privately owned rights. Reterence herein to any specific commercial product, process, or service by trade name, trademark, manufacturer, or otherwise, does not necessarily constitute or imply its endorsement, recommendation, or favoring by the United States Government or any agency thereof. The views and opinions of authors expressed herein do not necessarily state or reflect those of the United States Government or any agency thereof. 


\section{DISCLAIMER}

This report was prepared as an account of work sponsored by an agency of the United States Government. Neither the United States Government nor any agency Thereof, nor any of their employees, makes any warranty, express or implied, or assumes any legal liability or responsibility for the accuracy, completeness, or usefulness of any information, apparatus, product, or process disclosed, or represents that its use would not infringe privately owned rights. Reference herein to any specific commercial product, process, or service by trade name, trademark, manufacturer, or otherwise does not necessarily constitute or imply its endorsement, recommendation, or favoring by the United States Government or any agency thereof. The views and opinions of authors expressed herein do not necessarily state or reflect those of the United States Government or any agency thereof. 


\section{DISCLAIMER}

Portions of this document may be illegible in electronic image products. Images are produced from the best available original document. 


\section{Gamma and Beta Logging of Underground Sewer and Process Lines}
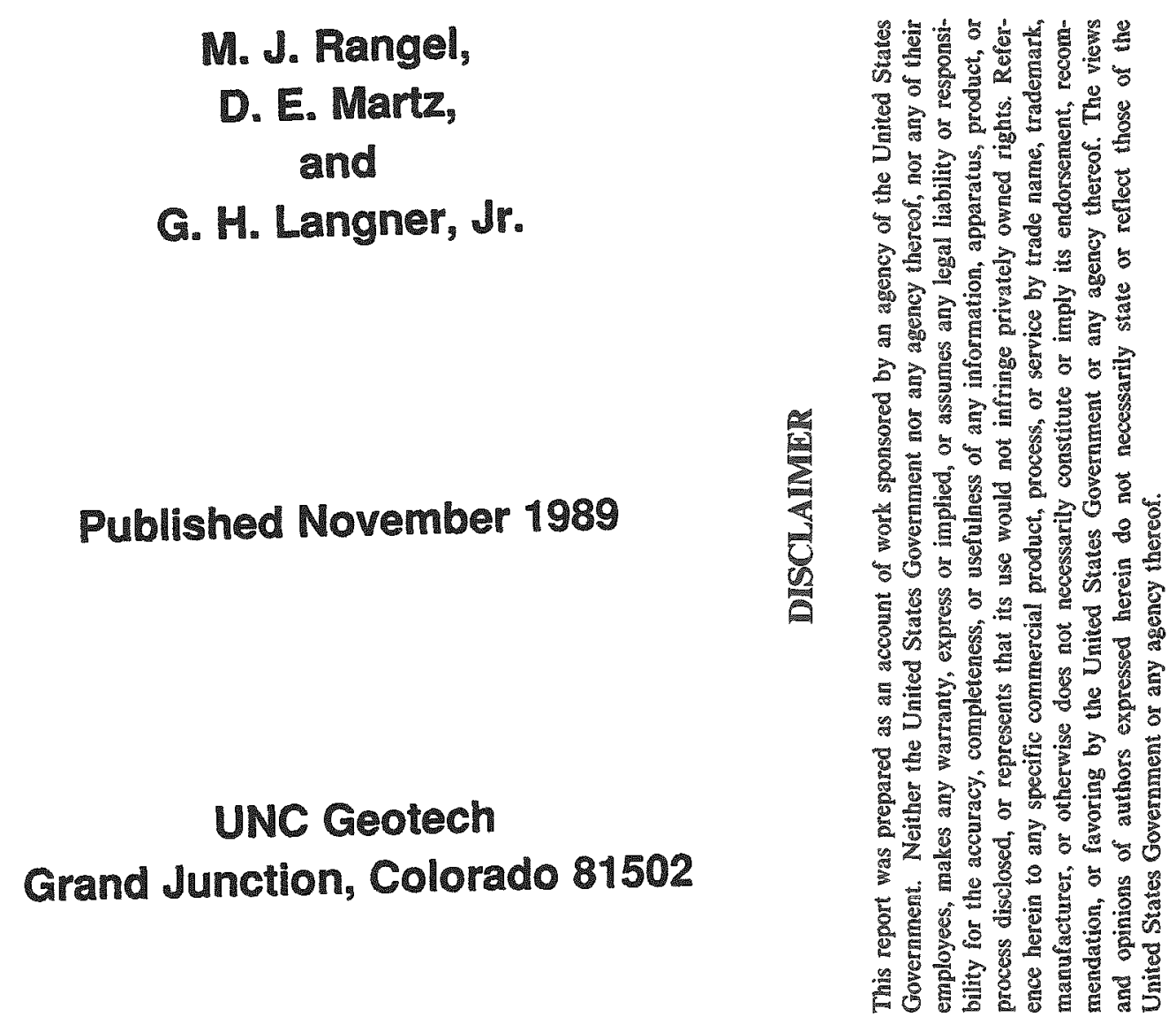

Prepared for

U.S. Department of Energy

Grand Junction Projects Office

Under Contract No. DE-ACO7-86ID12584 


\section{THIS PAGE WAS INTENTIONALLY LEFT BLANK}




\section{Contents}

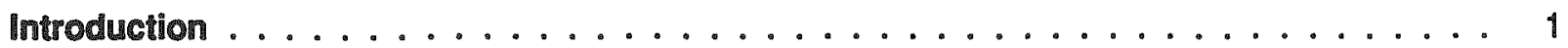

Purpose and scope $\ldots \ldots \ldots \ldots \ldots \ldots \ldots \ldots \ldots \ldots$

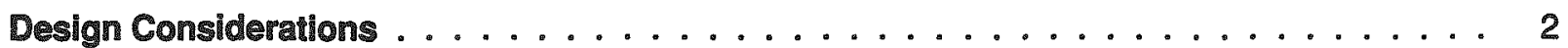

Description of the Gammasnake ....................... . . . 5

Operating Procedures for the GammaSnake . . . . . . . . . . . . . . . . . 10

Calibration of the GammaSnake ........................ 10

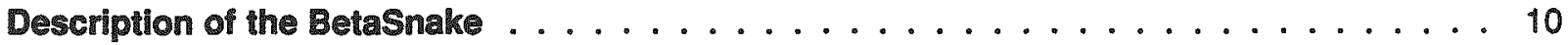

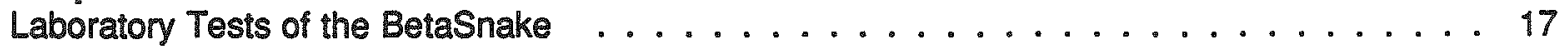

Line Locators . . . . . . . . . . . . . . . . . . . . . . . 17

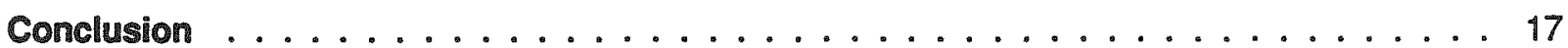

Figures

Figure 1. Gamma Energy Spectrum of Uranium Mill Tailings Observed with a

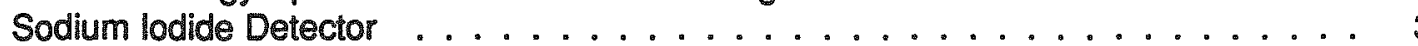

2. Gamma Energy Spectrum of Grand Junction Soil Observed with an Unshielded Sodium lodide Detector ... . . . . . . . . . . . . . . . . 4

3. Cross-Section Drawing of the GammaSnake 1 Detector . . . . . . . . . . . . 6

4. Cross-Section Drawing of the GammaSnake 2 Detector . . . . . . . . . . . . 7

5. GammaSnake Detector with 0.5-inch Crystal . . . . . . . . . . . . . 8

6. GammaSnake on Transport Reel ...................... . . 9

7. Data Sheet for GammaSnake . . . . . . . . . . . . . . . . . . 11

8. Cross-Section Drawing of BetaSnake Detector Design . . . . . . . . . . . 14

9. BetaSnake Detector Showing Radial Slots in the Detector . . . . . . . . . . 15

10. BetaSnake Detector on Transport Reel ................... . 16

\section{Tables}

Table 1. Uranium Pit Data for the 0.5-inch Sodium lodide Detector . . . . . . . . . . 12

2. Uranium Pit Data for the 1 -inch Sodium lodide Detector . . . . . . . . . . . 13 


\section{Gamma and Beta Logging of Underground Sewer and Process Lines}

\section{Introduction}

The Technical Measurements Center (TMC)

at the U.S. Department of Energy Grand

Junction Projects Office (DOE/GIPO) supports programs under the DOE Office of Remedial Action and Waste Technology, and is charged in part with developing and evaluating measurement protocols for DOE remedial action projects. UNC Geotech, as the operating contractor for the GJPO, is responsible for the DOE remedial action involving properties in and near Grand Junction, Colorado, that are contaminated with uranium mill tailings obtained from the nearby Climax Uranium Mill. Several thousand privately owned residential and commercial properties were contaminated during the 1950 s and 1960 s when sand from the tailings pile was used for various construction purposes. Common uses of the radium- and uranium-contaminated sand included backfill in and around building foundations, utility lines, and landscaping projects.

Mill tailings covered with less than 12 inches of uncontaminated soil usually can be located with a portable gamma scintillation detector from the gamma radiation emitted by specific daughter isotopes of the uranium decay series, primarily bismuth-214 and lead-214. In many cases, however, the uranium mill tailings that were used for construction purposes are covered with more than 3 feet of uncontaminated soil, making surface detection of the buried tailings much more difficult. The presence of a concrete or asphalt layer over shallow buried tailings also causes severe attenuation of the lower energy gamma rays emitted by uranium mill tailings.

Three methods are used by the GIPO field assessment crews to investigate sewer lines in the Grand Junction area where the presence of mill tailings is suspected. The first method involves digging with a shovel directly into the soil covering the sewer line and determining the increase in gamma radiation between the surface and the bottom of the hole. This is termed the shovel-hole investigation method with a delta gamma measurement. The second method is to auger a 3-inch diameter hole to a depth of 3 to 6 feet, and log the hole from the surface to the bottom with a cablesupported gamma detector and scaler. The third method is termed "backhoe engineering." During the remediation of the property, several pits are dug with a backhoe and the soil at depth is examined with a portable gamma scintillation counter. However, this latter method does not allow adequate advance planning for the remedial action process, and does not provide appropriate advance notification to the property owner and to the construction crew regarding the extent of the excavation.

Investigating sewer lines using the shovelhole method tends to be time consuming and, therefore, costly. Borehole drilling requires a significant amount of advance survey time to locate the exact position and depth of the sewer in order to avoid damage resulting from drilling into the line. Extreme care is also required to avoid drilling into water lines, electrical lines, or natural-gas lines that may be buried in the vicinity. Natural-gas lines and electrical lines pose serious hazards to equipment operators. Irrigation lines are not as hazardous, but can be easily damaged and cause inconvenience to the property owner. The available site maps seldom show the location of the various utility lines on the property with sufficient accuracy to permit drilling without additional on-site surveys. Magnetic or radio-frequency locators may be used to assist in the location of underground utility lines, but these instruments cannot trace nonmetallic lines without inserting a metal probe. Utility companies often are reluctant to permit digging or drilling in the vicinity of underground utility lines due to the hazard and cost required to repair the line if it is damaged.

\section{Purpose and Scope}

The UNC Geotech Radon Laboratory was assigned the task of developing a gammasensitive field instrument that would be capable of detecting the presence of uranium mill tailings used as backfill in sewer line trenches 
on commercial and residential properties in the Grand Junction area. A waterproof gamma detector mounted on a sewer snake, inserted into the clean-out access port, and pushed down the sewer line 45 to 90 feet, represented a promising field assessment tool for this purpose. A small sodium iodide gamma detector was expected to be capable of detecting the presence of tailings in the backfill without relying on extensive surveying and drilling. The instrument designed for this purpose was termed the GammaSnake.

The original concept of the GammaSnake was extended to include a beta-sensitive detector that could be inserted into underground process lines for determining the presence and location of residual beta emitting isotopes at formerly utilized DOE facilities. The instrument developed for this purpose was termed the BetaSnake.

\section{Design Considerations}

Prior to 1970, sewer lines in Mesa County, Colorado, were constructed from a variety of materials, including cast iron, concrete, orangeburg, acrylonitrile butadiene styrene (ABS), and polyvinyl chloride (PVC) plastic pipe. The typical older residence in Mesa County may be served by a sewer line between the residence and the street sewer of either 3 or 4 inches in diameter. The Mesa County building code now specifies 3- or 4-inch diameter ABS or PVC sewer pipe with a maximum of two 45 -degree bends following the clean-out access port; but some earlier installations have one or more 90-degree sanitary tees following the clean-out access port.

The maximum size of a gamma detector that can be inserted into a 4-inch diameter sewer line and traverse one or more 90-degree bends depends on both the diameter and length of the detector housing, but a practical maximum detector size for this purpose is less than 1.6 inches in diameter and less than 6 inches in length. A smaller detector housing is necessary for insertion around 45- or 90-degree bends in the 3-inch diameter sewer lines. A practical maximum envelope for the smaller lines is 1.2 inches in diameter and 5.5 inches in length.

A preliminary design concern was the shape of the nose of the detector that would permit the GammaSnake to be pushed around a 90-degree bend in the sewer line. Several prototype nose shapes were tested to determine the most efficient shape for following the bend of a 90-degree sanitary tee in either of the standard sized sewer lines. These prototypes included 45- and 60-degree nose tapers, paraboloids, and hemispherical nose. The testing also included traversing different types of pipe connectors such as 45- and 90-degree elbows and 45-degree tees. Problems were encountered with 45- and 60-degree tapered nose pieces. A hemispherical nose shape was found to be the most efficient of the prototypes tested.

Preliminary tests with samples of mill tailings and standard sewer pipe indicated that a sodium iodide scintillation crystal, with a volume of a few cubic centimeters and mounted on a small photomultiplier tube, could easily detect the gamma radiation field emitted by uranium mill tailings in the amounts normally used as backfill surrounding a typical residential sewer line. Testing also indicated that the voltage bias and signal pulses could be transmitted by a coaxial cable up to 100 feet in length without serious attenuation, eliminating the need for preamplification in the detector package. Gamma detectors other than sodium iodide were considered, including cesium iodide on an avalanche photodiode and cadmium telluride. Both of these detectors, although capable of being packaged in small and easily insertable configurations, lacked the required sensitivity for detecting the weak gamma fields associated with small quantities of uranium mill tailings around sewer lines.

The principal gamma rays emitted by uranium mill tailings from the Grand Junction Climax Mill tailings pile are the 242-keV, 295$\mathrm{keV}$, and 352-keV gamma rays from lead-214; and the $609-\mathrm{keV}, 1120-\mathrm{keV}$, and $1764-\mathrm{keV}$ gamma rays from bismuth-214, as illustrated in the gamma energy spectrum shown in Figure 1. These same isotopes are omnipresent in soil as members of the uranium decay series and, hence, provide a major fraction of the background radiation encountered by an unshielded gamma detector in uncontaminated soil. The background radiation from soil, shown in Figure 2, also includes a number of gamma rays emitted by daughter isotopes from the thorium-232 decay series, primarily 


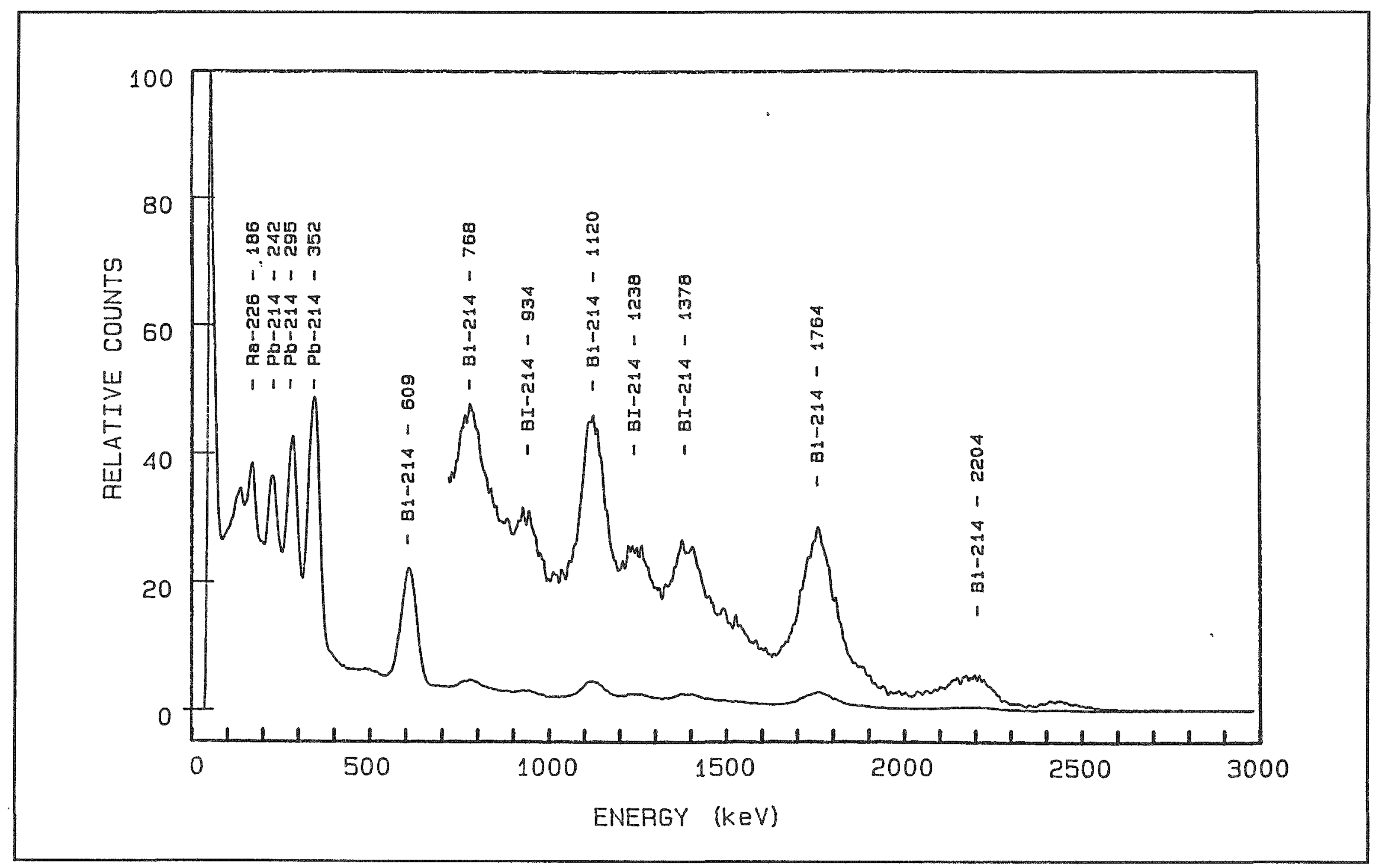

Figure 1. Gamma Energy Spectrum of Uranium Mill Tailings Observed with a Sodium lodide Detector (The major gamma energy peaks are labeled and a second trace of the spectrum above $700 \mathrm{keV}$ has been scaled up by a factor of 10 to show the higher energy peaks.) 


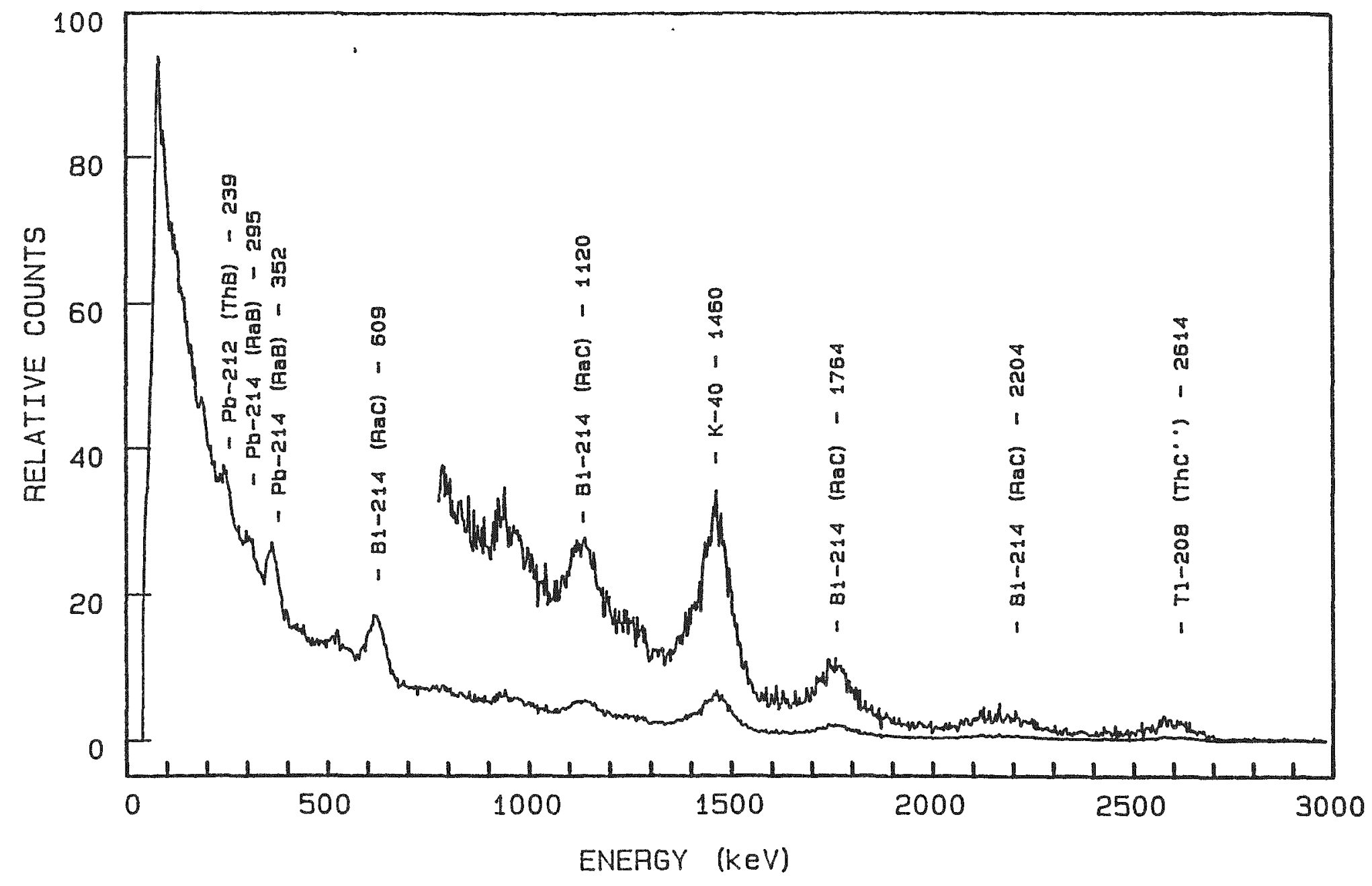

Figure 2. Gamma Energy Spectrum of Grand Junction Soil Observed with an Unshielded Sodium lodide Detector (All peaks with the exception of the 1460-keV K-40 peak are due to uranium and thorium daughters occurring naturally in soils.) 
the $239-\mathrm{keV}$ gamma ray from lead-212, the 583and $2614-\mathrm{keV}$ gamma rays from thallium-208, and the $911-\mathrm{keV}$ gamma ray from actinium228. The $1460-\mathrm{keV}$ gamma ray from potassium40 also contributes to the natural background. This gamma background is significantly degraded toward lower energies by multiple Compton scattering events, and there is an additional cosmic ray component at the surface. Preliminary testing indicated that no significant improvement in the signal-tonoise ratio could be achieved by energy discrimination.

The attenuation caused by a plastic or orangeburg sewer-pipe wall is not significant at energies above about $200 \mathrm{keV}$, and the somewhat greater attenuation of the mill tailings radiation by the wall of a typical cast-iron sewer pipe still permits easy detection of the surrounding tailings with a small sodium iodide scintillation crystal. Detectors used inside sewer lines must be waterproof, and the housing must be capable of withstanding the abrasion caused by sand and grit inside the sewer. The signal cable must also be protected, and the snake must be sufficiently flexible to traverse 90-degree bends, yet stiff enough to allow the detector to be pushed into the line for at least 100 feet.

\section{Description of the GammaSnake}

Two different configurations of the GammaSnake were designed and constructed. The first of these, as shown in Figure 3, was a 1-inch diameter by 1-inch long cylindrical sodium iodide crystal mounted on a 1-inch diameter Hamamatsu R1924 photomultiplier tube with the unit housed in a stainless steel case 5 inches in length and 1.5 inches in diameter. Both ends of the steel case were tapered at a 45-degree slope to allow the detector to traverse 90-degree bends. The detector unit was attached to a 50-foot length of a standard brand of flexible steel electrical conduit that was plastic-covered to render it waterproof. A 0.375 -inch by 0.0625 -inch spring steel sewer snake, with rounded corners to allow the snake to fit tightly inside the 0.375 -inch inside diameter of the conduit, was used to provide the necessary stiffness to the overall 50 -foot length of the GammaSnake. The remaining interior cross section of the conduit was sufficient for the 0.105-inch diameter RG 174/U coaxial cable used to transmit the voltage bias and signal pulses to the electronic counter. A voltage bias of 800 volts supplied to the photomultiplier tube provided an adequate signal-to-noise ratio for mill tailings radiation against the typical uranium/thorium daughter background.

The second configuration of the GammaSnake is shown in Figures 4,5, and 6. This smaller version was designed for easier insertion around 90-degree bends. The sodium iodide crystal for this detector was 0.5 -inch diameter by 0.5 -inch long, and was mounted directly on a 0.5 -inch diameter Hamamatsu Model R647 photomultiplier tube. The 1-inch outside diameter by 4.8-inch long stainless steel housing was rounded to a hemispherical shape at the front, with a machined 0.5 -inch extension at the rear to permit attachment of the standard 0.5 -inch diameter plastic covered electrical conduit. A similar tensile steel snake was used to produce the necessary stiffness for insertion of this longer GammaSnake for distances up to 100 feet into the sewer line.

Any of several portable commercial counter/scalers suitable for operation with photomultiplier detectors can be used with the GammaSnake detectors. The scalers must provide the required high voltage bias supply, and should provide both an analog ratemeter and a digital counter. Analog ratemeters are easier to read in bright outdoor lighting than light-emitting diode (LED) or liquid crystal displays (LCD). The GammaSnake has operated successfully with the Eberline ESP-1 Smart Portable, the Bicron Labtech, and Ludlum Model 2200 portable scalers.

The Eberline ESP-1 Smart Portable is a microcomputer-based portable radiation survey instrument designed to operate with a variety of radiation detectors. Most technicians in the GIPO UMTRA Field Assessments Section have been trained in the use of the ESP-1 using sodium iodide detectors; hence, it was an obvious choice for the two GammaSnakes provided to the Field Assessments Section. The unit has a LCD display and a series of push-button switches for setting parameters. The high-voltage bias controls are internal and 
क

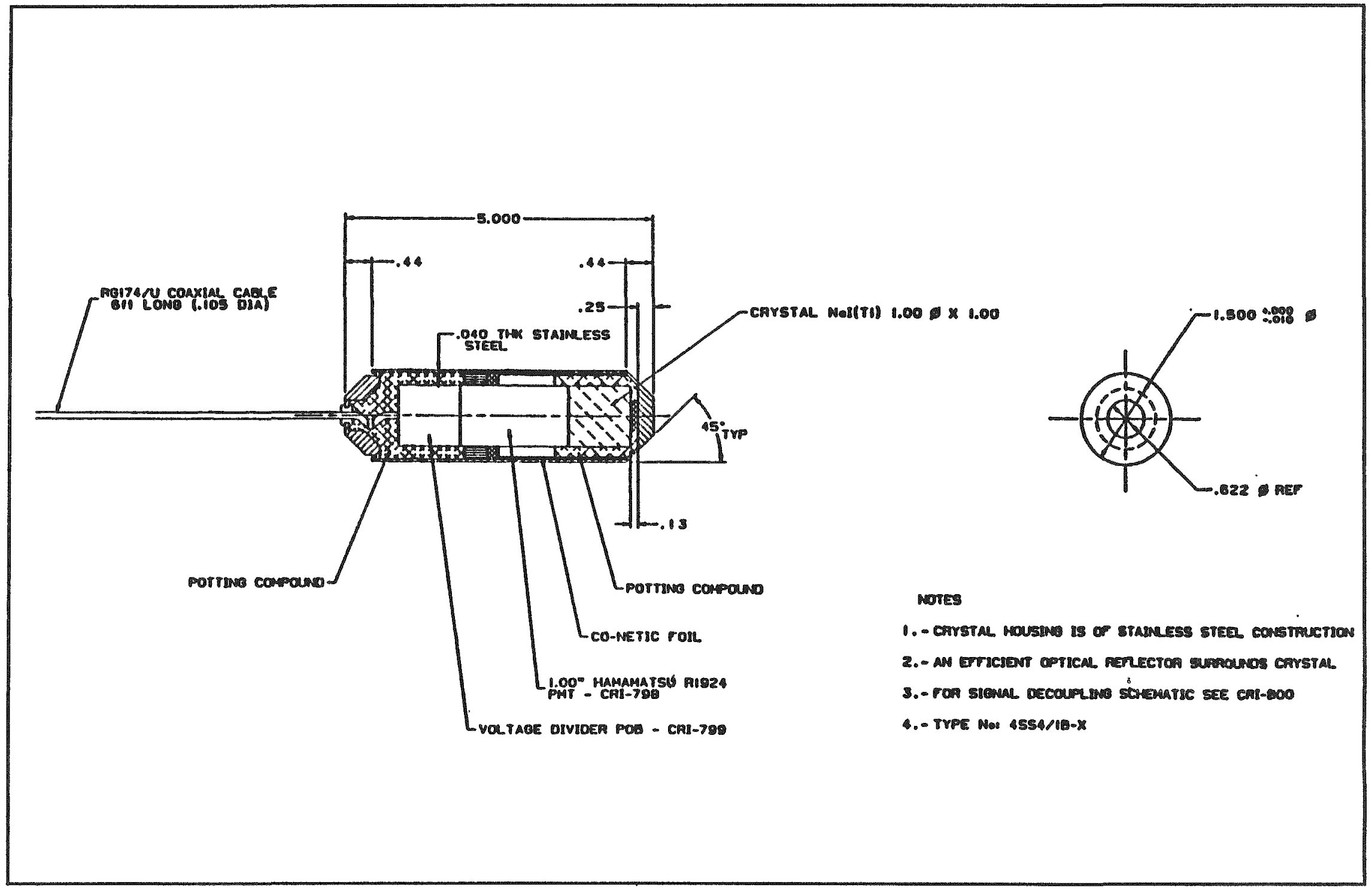

Figure 3. Cross-Section Drawing of the GammaSnake 1 Detector (The stainless steel housing was connected to a plastic covered flexible electrical conduit not shown.) 


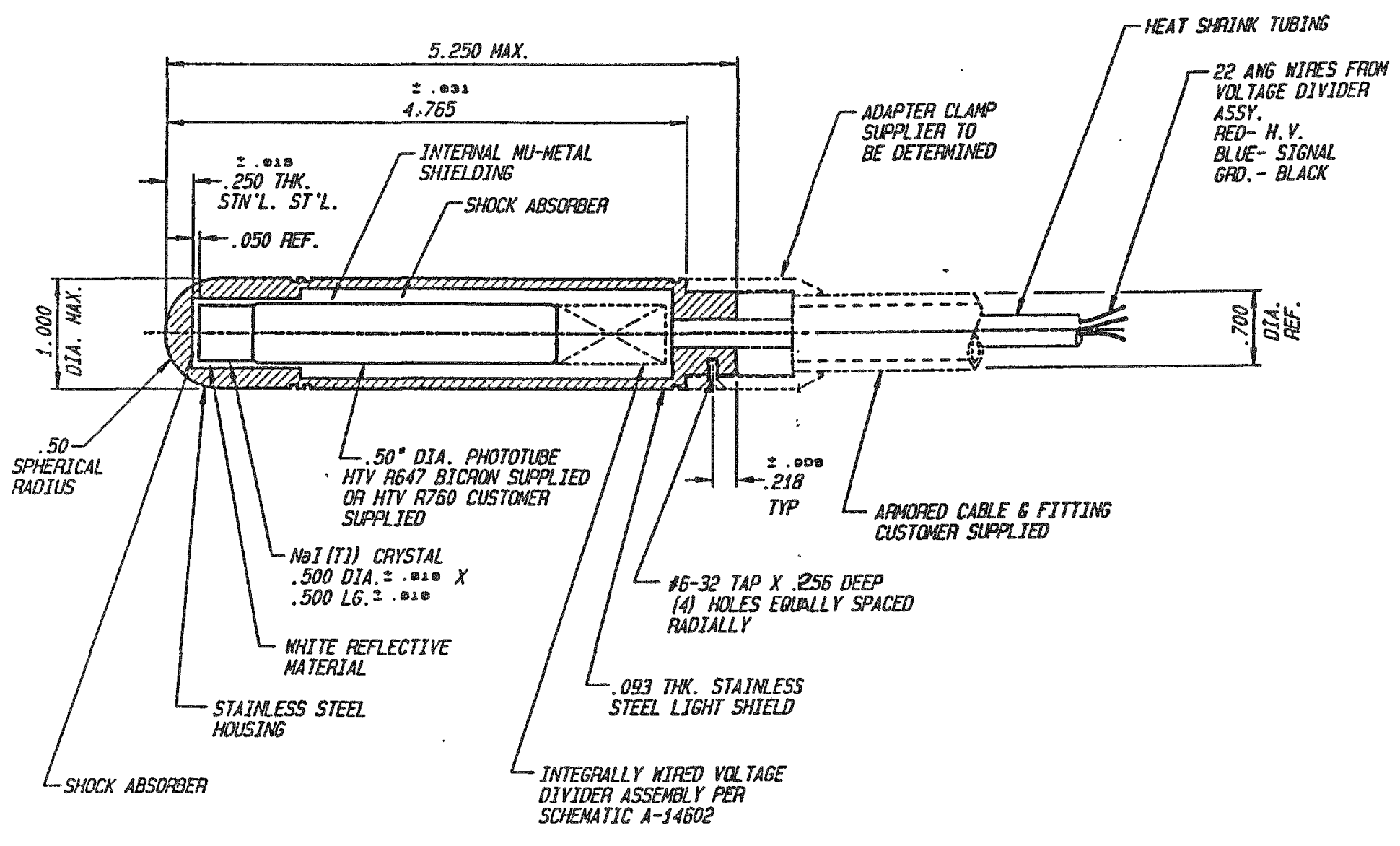

Figure 4. Cross-Section Drawing of the GammaSnake 2 Detector 


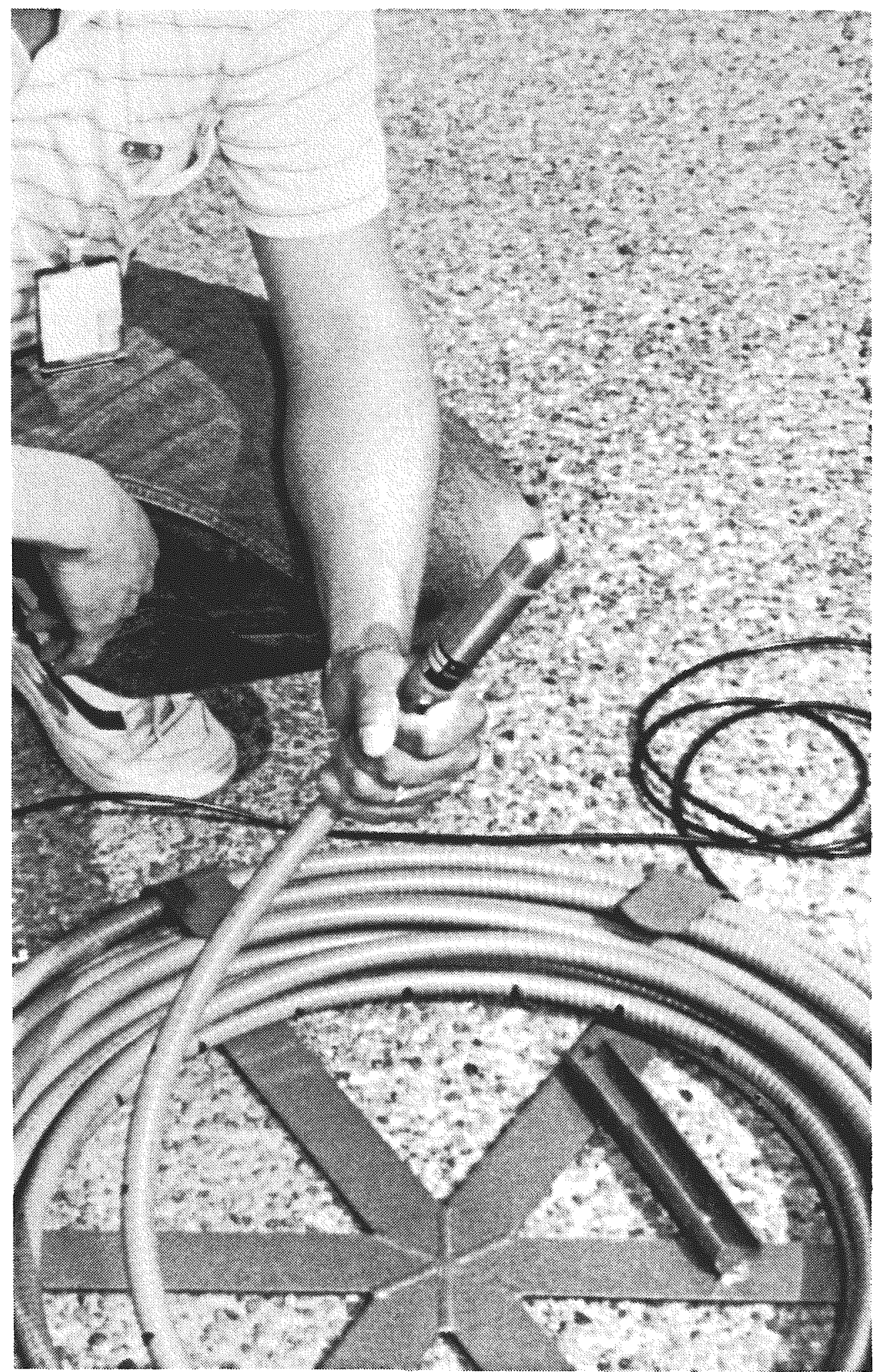

Figure 5. GammaSnake Detector with 0.5-inch Crystal 


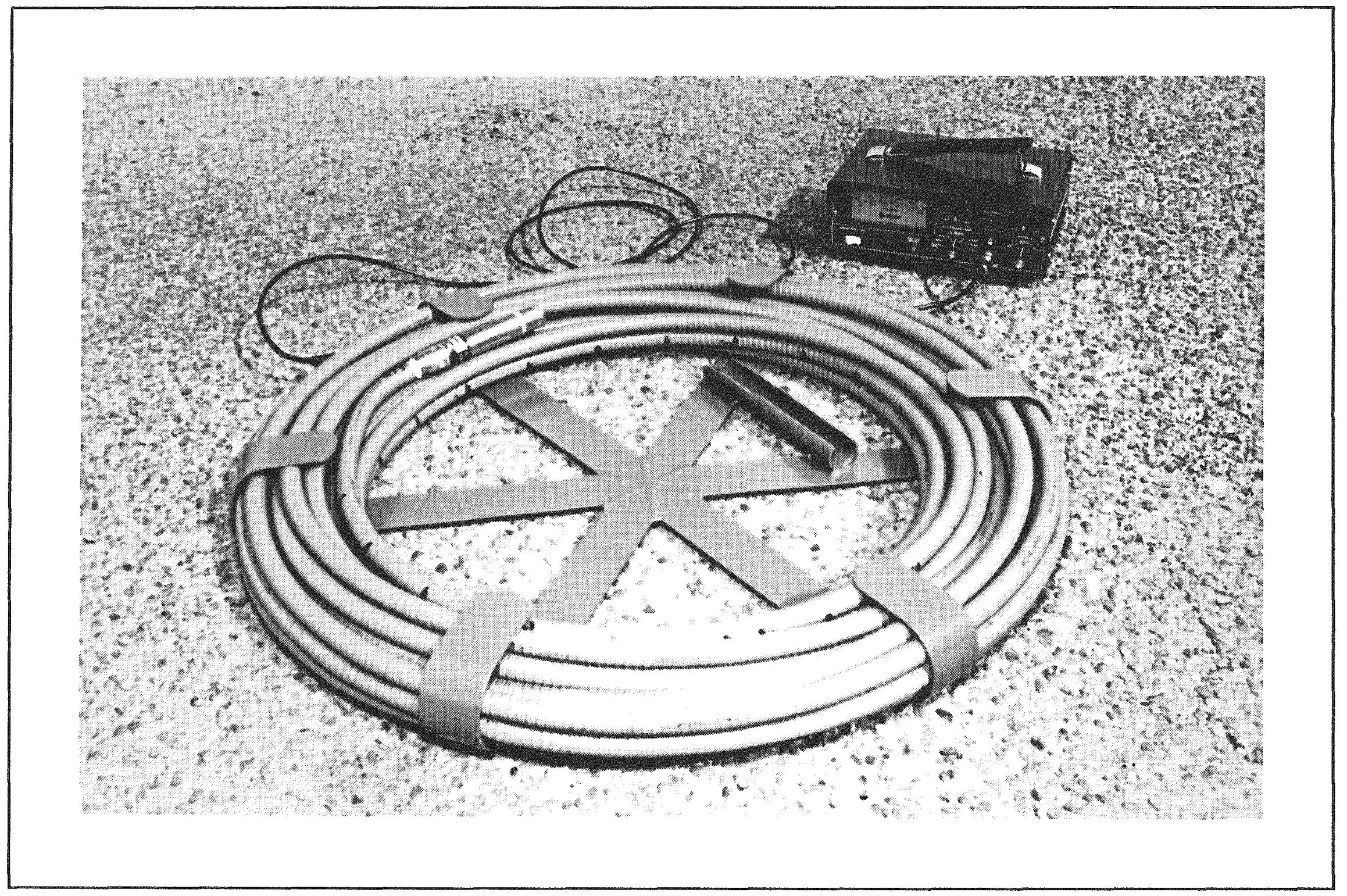


are normally set by electronics technicians during calibration of a specific detector.

\section{Operating Procedures for the GammaSnake}

1. Locate the clean-out access port or other access to the sewer line.

2. Carefully unreel the GammaSnake from its transport reel, taking care to prevent the detector impacting against the ground or pavement due to the stiffness of the snake.

3. Connect the 12-foot coaxial cable between the BNC connector on the terminal end of the GammaSnake to the scaler input.

4. Turn on the high voltage bias if previously set, or set to 800 volts.

5. Check the GammaSnake with a standard gamma source to determine if the signal falls within the normal range with the detector on the soil surface.

6. Some sewer lines may have been damaged or may have tree roots blocking the line. Using a dummy snake or probe to check the line prior to insertion of the GammaSnake can avoid damage to the instrument.

7. Insert the detector into the sewer access opening and push the snake into the sewer as far as desired. Note the distance by the position marks on the snake.

8. Observe the count rate on the scaler and record the information on the field data sheet (Figure 7) as the GammaSnake is inserted to determine if mill tailings are present.

9. If the gamma signal indicates mill tailings are present, it may be desirable to mark out the position of the sewer line on the surface with a magnetic or radio-frequency locator using the steel conduit of the GammaSnake as the target or antenna.

10. The approximate extent of the mill tailings can be determined by logging the gamma count rate as a function of distance as measured by the distance marks on the GammaSnake as the snake is removed.

11. Clean the GammaSnake with a water hose and/or disinfectant wipes and return it to the transport reel.

\section{Calibration of the GammaSnake}

Both versions of the GammaSnake have been calibrated in the mill tailing test pit at the GIPO. Table 1 shows the observed gamma count rate recorded for the 0.5 -inch sodium jodide GammaSnake as a function of depth in the Uranium Pit. Table 2 shows similar data for the 1-inch diameter sodium iodide GammaSnake in the same pit. The gamma count rate for the larger detector is greater by about a factor of six compared with the smaller crystal. However, the background count rate ratio for the two GammaSnakes in uncontaminated soil is also about a factor of six, therefore, the signal-to-noise ratios for the two systems are nearly equal for a given amount of contamination.

\section{Description of the BetaSnake}

The design of a beta detector for the BetaSnake was based on the assumption that the primary beta contamination at sites where aged fission products are present will always include as a major component strontium-90/yttrium90 with a maximum beta energy of $2284 \mathrm{keV}$, and that the principal beta contamination for uranium processing sites will include the protactinium-234 daughter from the uranium-238 decay chain with a maximum beta energy of $2281 \mathrm{keV}$. A large fraction of the beta particle energies would be expected to be absorbed in the scale and debris lining the interior of the process line, but it is assumed some highenergy beta particles would impinge on the detector. The thinnest practical light-tight window capable of protecting a plastic scintillator beta detector from the abrasion encountered due to sand and debris inside a process line was estimated to be about 0.010 inch. Only beta particles with energies greater than about 300 $\mathrm{keV}$ can penetrate this thickness of aluminum.

The BetaSnake detector, shown in Figures 8, 9 , and 10, was designed as a coaxial Bicron BC-444 plastic scintillation sleeve surrounding a nonscintillating Lucite TM light pipe. The purpose of the coaxial design was to maximize the beta response while minimizing the response of the plastic scintillator to gamma radiation. A 0.010-inch-thick aluminum watertight window allowed the higher energy beta particles to reach the plastic scintillator 


\section{SEWER IIIE INVESTIGATION DATA SIEET MODEL PRS-1/ESP-1/ESP-2}

DOF ID NUMBER :

AWDRESS :

DATE:

OPFRATOR:

GRID LOCATION NUMBER :
MODEL TYPE:

INSTRUMENT GJPO NUMBER:

CALIBRATION EXPIRES :

DEPTH OR LINE FEET INCHES

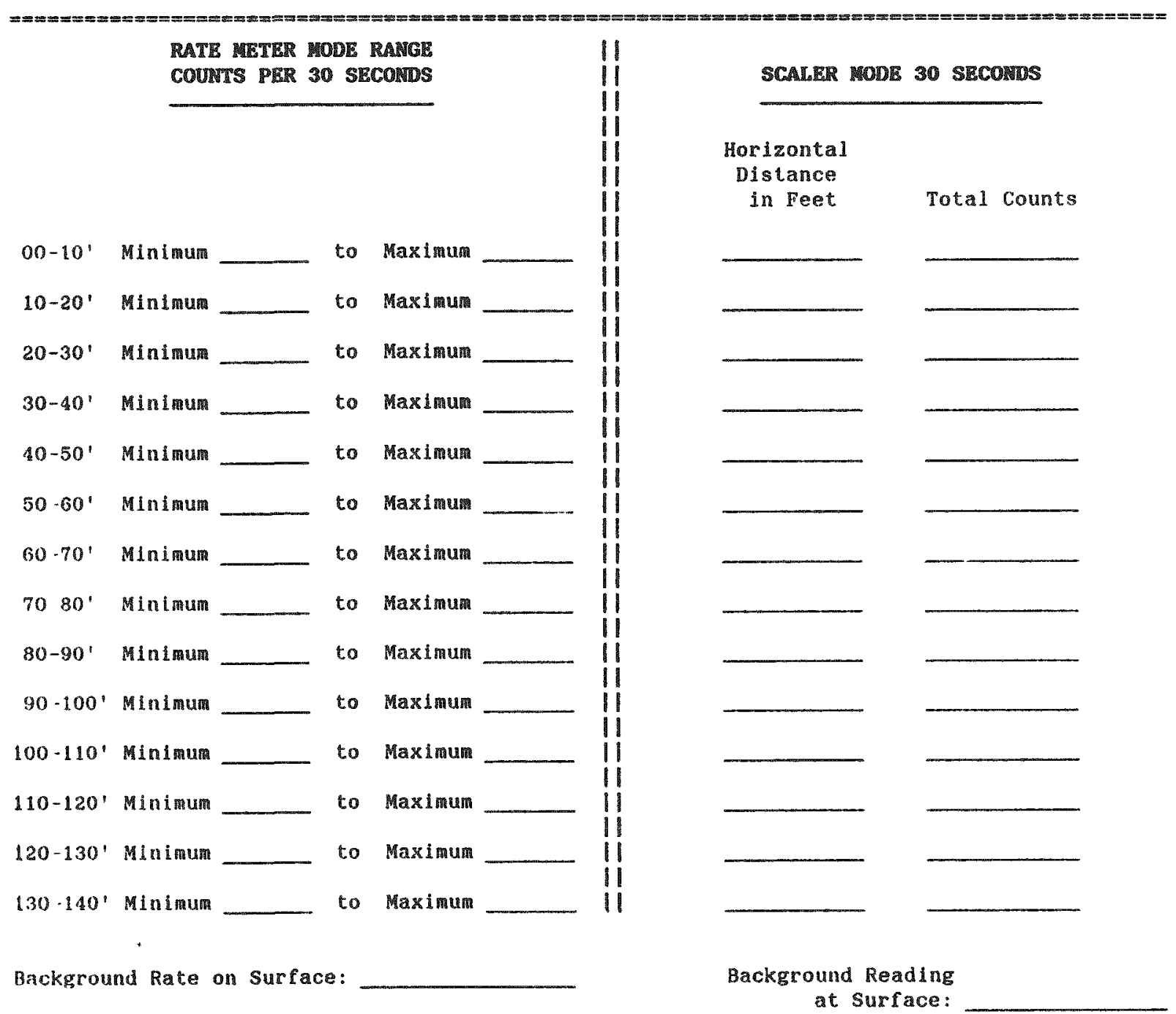

SWFR-LNF. FRM: FORMS 1988-1989: 11/13/89:pr 
Table 1. Uranium Pit Data for the 0.5-inch Sodium lodide Detector

\section{CALIBRATION DATA SHEET}

Galib V7.2 <880111>

12: $0 \quad 7$ NOV, 1989

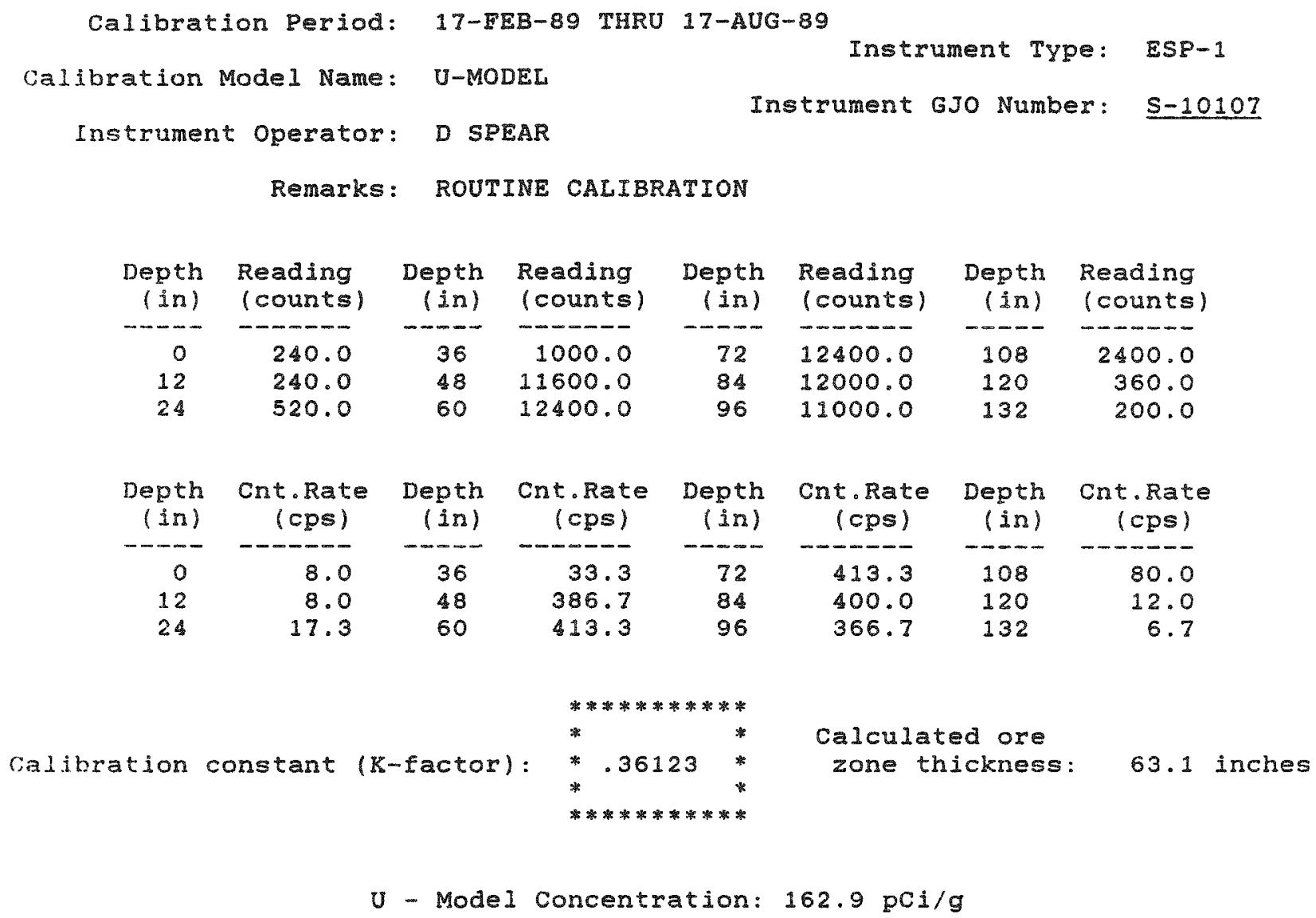


Table 2. Uranium Pit Data for the 1-inch Sodium lodide Detector

\section{CALIBRATION DATA SHEET}

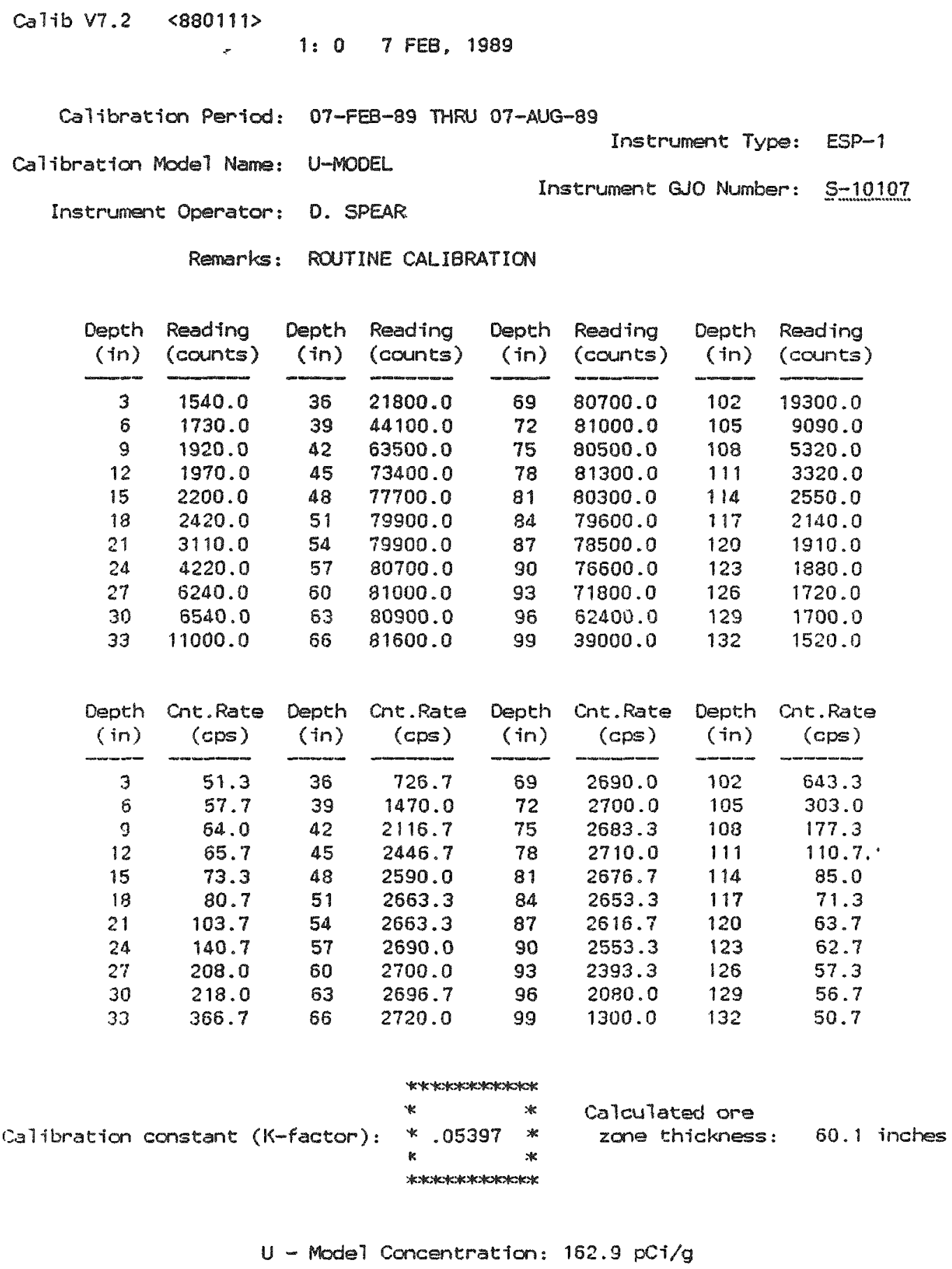




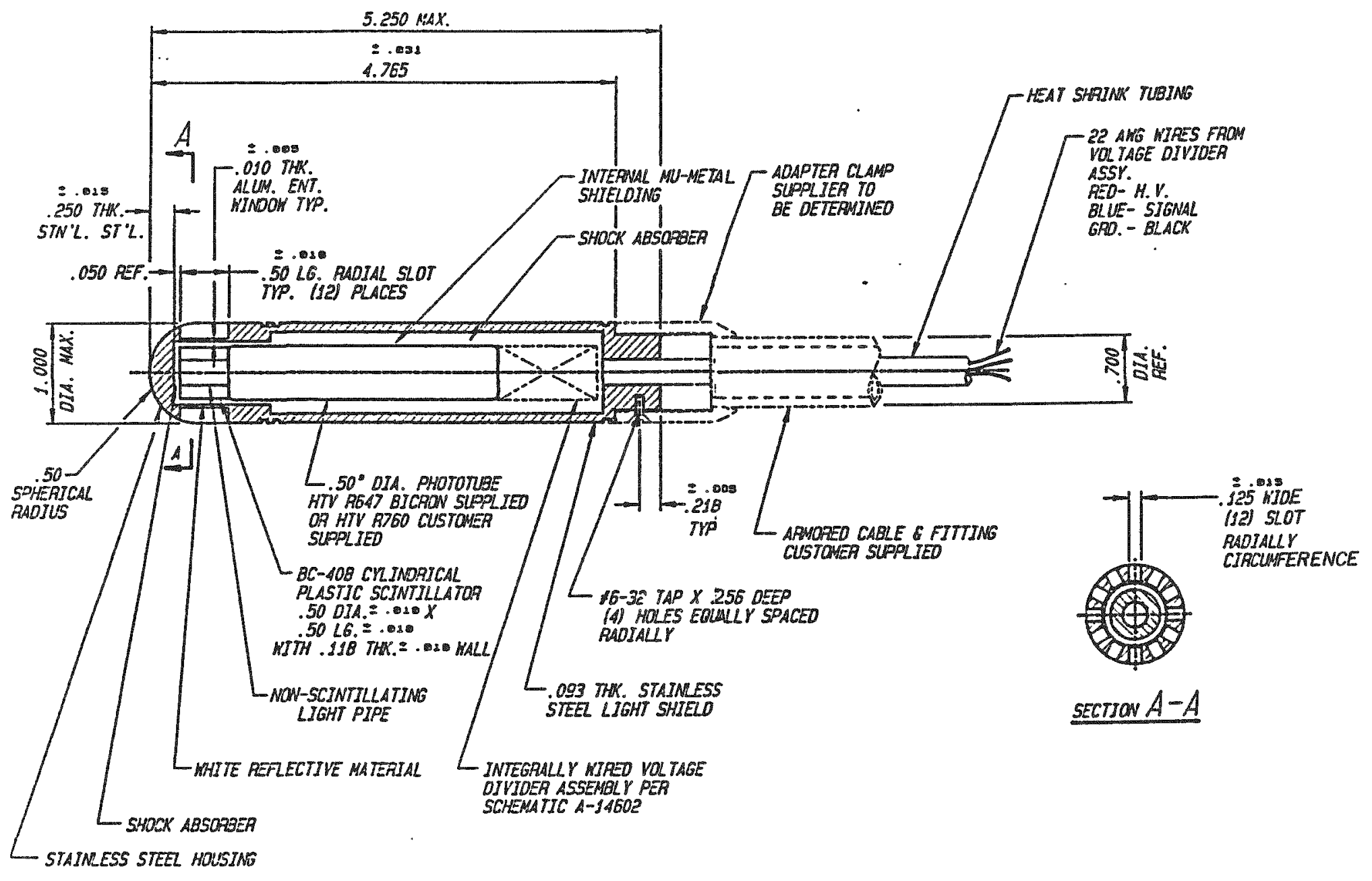

Figure 8. Cross-Section Drawing of BetaSnake Detector Design 


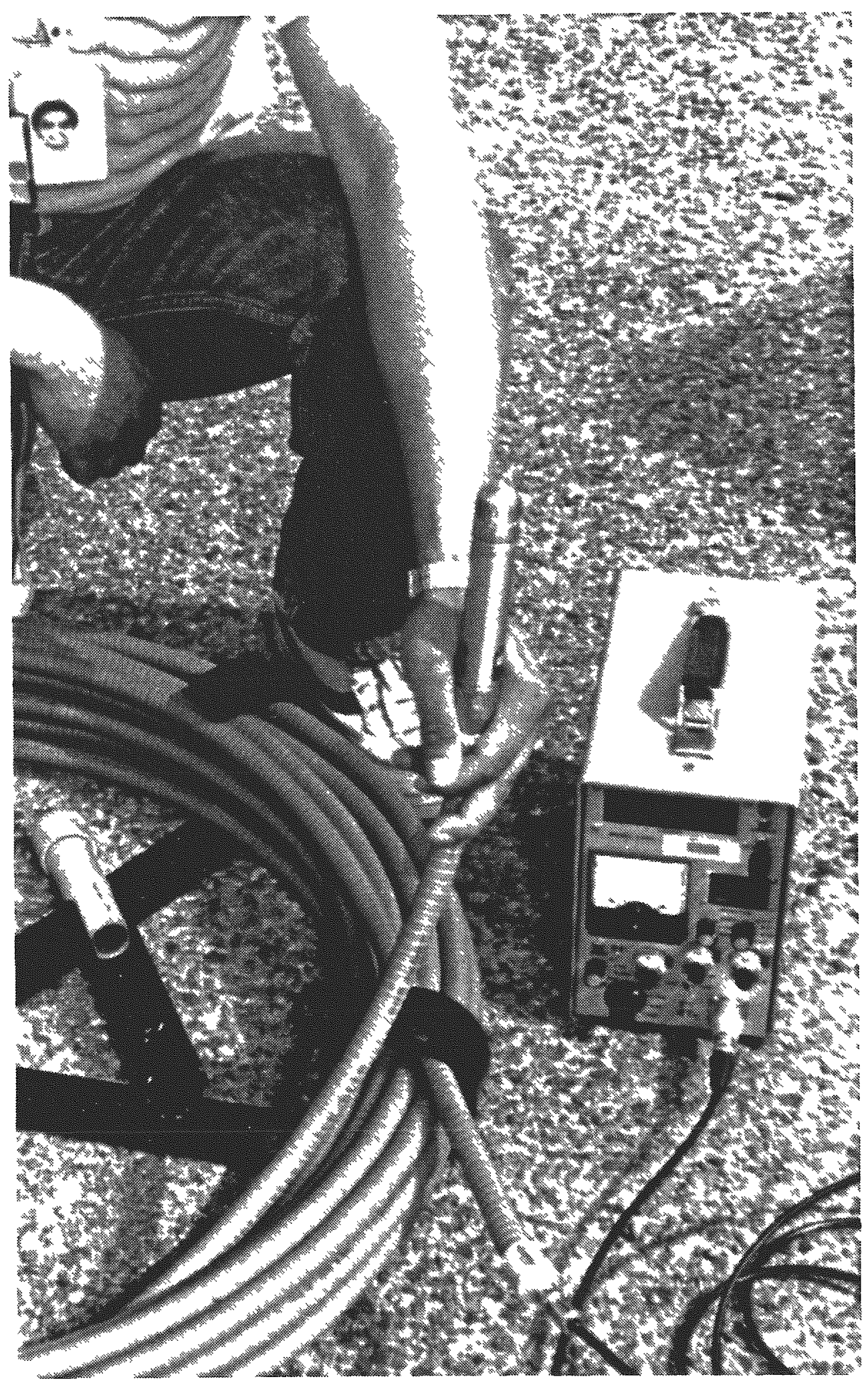

Figure 9. BetaSnake Detector Showing Radial Slots in the Detector 


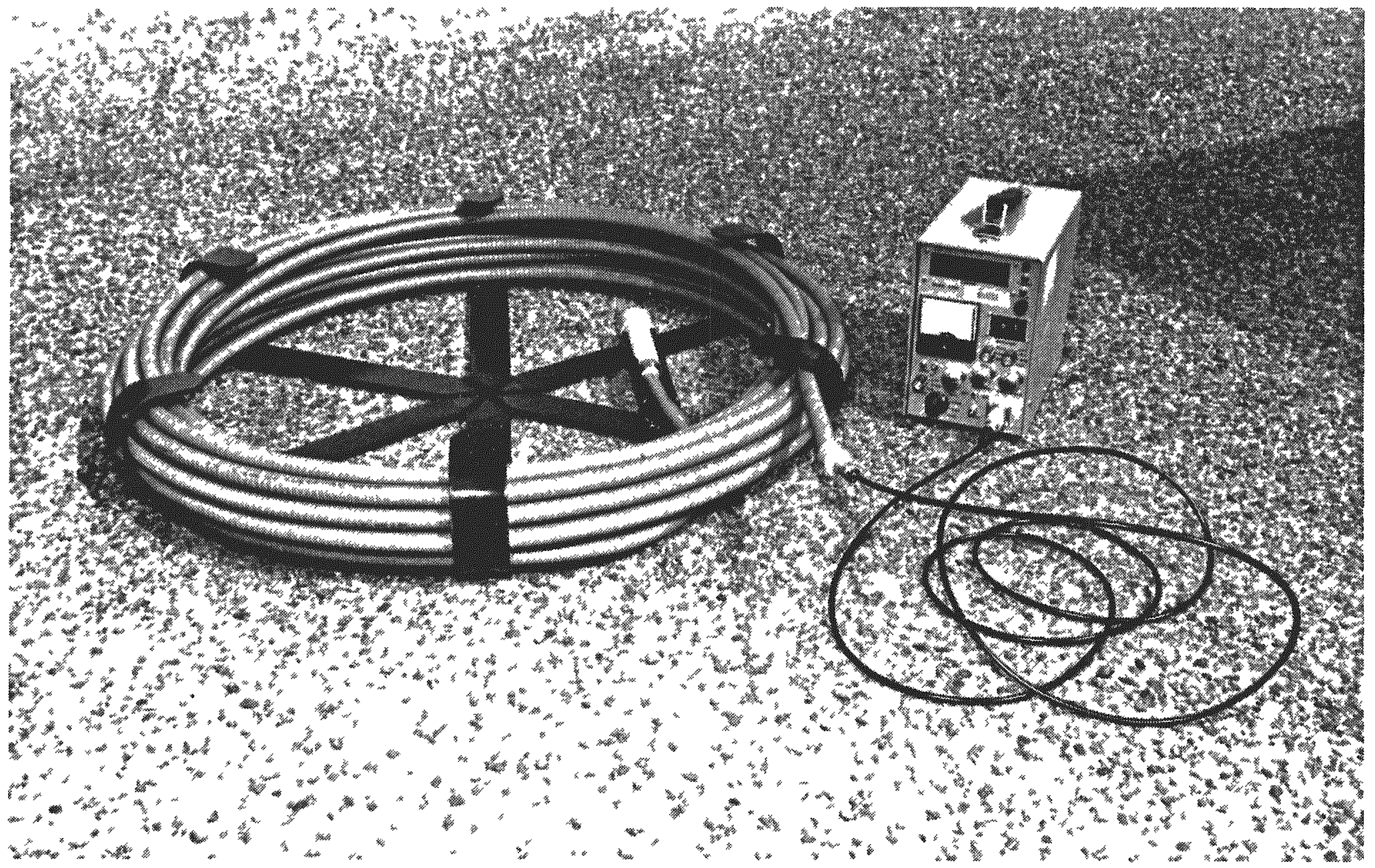


through radial slots milled in the stainless steel housing, with the steel ribs providing additional protection for the thin window. The BetaSnake detector was attached to a watertight flexible steel electrical conduit, with a spring steel sewer snake and signal cable identical to those used for the GammaSnake. A 1100-volt bias was used on the 0.5-inch diameter Hamamatsu R647 photomultiplier to amplify the weaker beta pulses for transmission along the 100-foot-long signal cable.

\section{Laboratory Tests of the BetaSnake}

Only laboratory tests of the BetaSnake have been conducted due to unavailability of a process line with significant beta contamination. The assembled BetaSnake was tested with a 0.09-microcurie pure strontium-90/yttrium-90 beta source using a Bicron Labtech ratemeter as the counter. A bias voltage of 1100 volts was used and the internal threshold discriminator on the Labtech was reduced to the lowest possible setting above instrument noise. Count rates of 2000-2700 counts per minute were observed with the source in close proximity with the ribbed window, and this source could be detected above instrument noise at distances up to 20 inches in the air from the detector.

\section{Line Locators}

A line locator is useful for locating the position and depth of a contaminated sewer line. Several commercial units are available; however, the unit chosen for this particular application was the Schonstedt Model MAC-51B. This unit operates both as a magnetic and a radiofrequency locator. The unit has an optional mini-transmitter that can be attached to a regular sewer snake and inserted into a sewer line. With the Model MAC-51B operated in the radio-frequency mode, the mini-transmitter provides a strong signal through the plastic sewer lines and through a few meters of earth.
The mini-transmitter is effective for locating PVC, ABS sewer lines, and may be used to locate septic tanks to a depth of 18 feet. The MAC-51B may be used without the mini-transmitter by coupling the radio-frequency signal to the exposed end of the GammaSnake, and using the steel conduit of the GammaSnake as an antenna.

When the locator is used in the magnetic mode for sensing buried ferromagnetic materials, the receiver responds to the different magnetic field intensities indicated by two sensors located 20 inches apart. The audio frequency emitted by the speaker is a low hum when no ferromagnetic material is present. When the locator is passed above a ferromagnetic object, the audio frequency will increase. The GammaSnake steel conduit, sewer-snake stiffener, and steel-detector housing provide the ferromagnetic material needed for detecting plastic sewer lines. The locator should be used with the probe end held vertically and as close to the ground as possible. When other ferromagnetic objects are in the surveyed area, it may be necessary to decrease the sensitivity adjustment, or change to the radio-frequency mode.

\section{Conclusion}

The GammaSnake can be useful for locating uranium mill tailings used as backfill for sewer lines or storm drains where the lines can be readily accessed from a cleanout access port or other opening. The time required to determine if contamination is present using the GammaSnake method is considerably less than when using the delta gamma or drilling methods. There is, also, less potential hazard to the equipment operators when using the GammaSnake method. The GammaSnake method is generally limited to a distance of 100 feet or less. Used with the MAC-51B line locator, the GammaSnake method can provide useful information without extensive drilling or surveying. 
Publications Issued by the Technical Measurements Center

November 1989

Operated by

UNC Geotech

for

U.S. Department of Energy

Office of Remedial Action and Waste Technology

Idaho Operations Office

Grand Junction Projects Office 


\begin{tabular}{|c|c|c|}
\hline Number & & Title (Authors) \\
\hline GJ/TMC-01* & & Field Calibration Facilities for Environmental Measurement of Radium, \\
\hline 2nd Edition & $\because$ & Thorium, and Potassium. (W. D. Steele and D. C. George) \\
\hline GJ/TMC-02 & & $\begin{array}{l}\text { Review of Selected DOE Remedial Action Field Measurement Procedures for the } \\
\text { Summer of 1982. (TMC Staff) }\end{array}$ \\
\hline GJ/TMC-03* & & $\begin{array}{l}\text { Abbreviated Total-Count Logging Procedures for Use in Remedial Action. } \\
\text { (D. C. George and R. K. Price) }\end{array}$ \\
\hline GJ/TMC-0.4* & & $\begin{array}{l}\text { Evaluation of Methods for the Estimation of Indoor Radon Daughter } \\
\text { Concentrations for Remedial Action Programs. (G. H. Langner, Jr., } \\
\text { J. C. Pacer, V. G. Johnson, and M. A. Gillings) }\end{array}$ \\
\hline GJ/TMC-05* & & $\begin{array}{l}\text { Feasibility Study of the Prompt Pb-214, Bi-214 Gamma Method for } \\
\text { Determining Radon Migration Through Tailings. (L. R. Stieff, The Stieff } \\
\text { Research and Development Co., Inc., Kensington, Maryland) }\end{array}$ \\
\hline GJ/TMC-06* & & $\begin{array}{l}\text { Surface Gamma-Ray Measurement Protocol. (S. J. Marutzky, W. D. Steele, } \\
\text { and B. N. Key) }\end{array}$ \\
\hline GJ/TMC $-07^{*}$ & & $\begin{array}{l}\text { Procedures for Field Chemical Analyses of Water Samples. (N. Korte and } \\
\text { D. Ealey) }\end{array}$ \\
\hline GJ/TMC $-08^{*}$ & & Procedures for the Collection and Preservation of Groundwater and Surface \\
\hline 2nd Edition & & $\begin{array}{l}\text { Water Samples and for the Installation of Monitoring Wells. (N. Korte and } \\
\text { P. Kearl) }\end{array}$ \\
\hline $\begin{array}{l}\text { GJ/TMC-09* } \\
\text { 2nd Edition }\end{array}$ & & $\begin{array}{l}\text { Protocol for the Estimation of Average Indoor Radon-Daughter Concentrations. } \\
\text { (G. H. Langner. Ir. and J. C. Pacer) }\end{array}$ \\
\hline G)/TMC-10* & & $\begin{array}{l}\text { Development of Solid Radium-226 Reference Materials. (R. B. Chessmore and } \\
\text { P. R. Engelder) }\end{array}$ \\
\hline $\begin{array}{l}\text { Letter Report } \\
\text { (unnumbered) }\end{array}$ & & $\begin{array}{l}\text { Supplemental Measurements for Polonium-210 and Lead-210 in TMC Radium } \\
\text { Reference Material (insert to GJ/TMC-10). (S. Donivan) }\end{array}$ \\
\hline G]/TMC-11* & & $\begin{array}{l}\text { Procedure Manual for the Estimation of Average Indoor Radon-Daughter } \\
\text { Concentrations Using the Radon Grab-Sampling Method. (J. L. George) }\end{array}$ \\
\hline GJ/TMC-12* & & $\begin{array}{l}\text { Procedure Manual for the Estimation of Average Indoor Radon-Daughter } \\
\text { Concentrations Using the Radon Progeny Integrating Sampling Unit (RPISU) } \\
\text { Method. (G. H. Langner, Jr.) }\end{array}$ \\
\hline GI/TMC-13* & & Procedures for Sampling Radium-Contaminated Soils. (H. L. Fleischhauer) \\
\hline
\end{tabular}


Number

GJ/MC-14*

GI/TMC-15*

GI/TMC-16*

GI/TMC $-17 *$

GI/TMC-18*

GI/TMC-19*

G) $/ \mathrm{TMC}-20$

GJ/TMC-22*

Letter Report (unnumbered)

GJ/TMC-23

G]/TMC-24:

GJ/TMC-25*

GJ/TMC-26*

G) $/ \mathrm{TMC}-27$ *
Title (Authors)

Procedures for Reconnaissance Stream-Sediment Sampling. (H. L. Fleischhauer and P. R. Engelder)

A Feasibility Study of the Use of Nuclear-Emulsion Technigues in the Study of Drill Core and Water Samples from the Monticello Mill, Monticello, Utah.

(L. R. Stieff, The Stieff Research and Development Co., Inc., Kensington, Maryland)

Test and Evaluation of Selected Instruments for Surface Gamma-Ray Measurements. (B. N. Key)

Calibration-Pad Parameter Assignments for In-Situ Gamma-Ray Measurements of Radium, Thorium, and Potassium. (D. C. George, E. F. Novak, and R. K. Price)

Operating Manual for the Radon-Daughter Chamber. (G. H. Langner, Ir., and T. Nelson)

Laboratory Intercomparison of Analytical Results on Samples Contaminated by Uranium Mill Tailings. (N. Korte, M. Hollenbach, and S. Donivan)

Radon-Daughter Chamber Instrumentation System Reference Manual. (L. Johnson and R. Showalter)

Development of Solid Thorium-232 Reference Materials. (P. R. Engelder, S. Donivan, and R. B. Chessmore)

Supplemental Measurements for Radium-226 and Potassium-40 in TMC Thorium Reference Material (insert to GJ/TMC-22). (S. Donivan)

Gamma-Ray Instrument Calibration Comparison Workshop. (W. D. Steele, D. C. George, and J. L. Burnham)

Comparison of In-Situ and Laboratory Measurement Methods for Radium-226 in Soils. (S. J. Marutsky, H. L. Fleischhauer, and P. R. Engelder)

Interlaboratory Radon-Daughter Measurement Comparison Workshop: 9-12 September 1985. (M. Pearson)

Field Study of Indoor Average Radon-Daughter Estimation Methods. O. L. George and G. H. Langner, Ir.)

Assessment of Mobile Gamma-Scanning Van Activities in Edgemont, South Dakota. (U.S. Department of Energy Task Force)

\footnotetext{
Available from National Technical information Service, U.S. Department of Commerce, 5285 Port Royal Road, Springtield, Virginia 22161, (703) 487-4600.
} 
Number

GI TMC-28*

UNC/GJ-29(TMC)

UNC/GJ-31(TMC)

UNC/GJ-32(TMC)

UNC/GJ-33(TMC)*

UNC/GJ-34(TMC)*

UNC/G]-35(TMC)*

UNC/GJ-36 (TMC)*

UNC/GI-TMC-1

UNC/GJ-TMC-2

UNC/GJ-37(TMC)*

UNC/GJ-38 (TMC)*

UNC/GJ-39(TMC)

UNC/GJ-40(TMC)

UNC/G]-41(TMC)*

$\mathrm{UNC} / \mathrm{GI}-42(\mathrm{TMC})^{*}$
- Tirle (Authors)

Interin Results of the Prompt Alpha-Track Radon Detector Study. O. L. George and G.,H. Langner, Jr.)

Comparison of Radon and Radon-Daughter Grab Samples Obtained During the Winter and Summer. (K. E, Karp)

Investigation of the Hammer-Gamma Measurement Technique: A Feasibility Study. (R. Showalter)

Construction and Characterization of the TL/TH Thorium Calibration Pads. (W. Douglass Steele)

Validation of the Prompt Alpha-Track Method. O. L. George and G.H. Langner, Jr.)

Validation of the Abbreviated Radon Progeny Integrating Sampling Unit (RPISU) Method for Mesa County, Colorado. (G. H. Langner, Jr.)

Construction and Testing of a Blower-Door Assembly for Regulation of Air Pressure Within Structures. (W. Douglass Steele)

Uranium Reference Materials. (S. Donivan and R. B. Chessmore)

Determination of Radon Sources at Four Vicinity Properties in Edgemont, South Dakota. (K. E. Karp)

Radon-Daughter Grab-Sampling Technical Exchange Meeting 14-17 April 1986. (M. D. Pearson)

Soil-Based Uranium Disequilibrium and Mixed Uranium-Thorium Series Radionuclide Reference Materials. (S. Donivan and R. B. Chessmore)

The Use of Atomic Absorption Spectroscopy to Measure Arsenic, Selenium, Molybdenum, and Vanadium in Water and Soil Samples From Uranium Mill Tailings Sites. (M. H. Hollenbach)

Procedure Manual for the Estimation of Average Indoor Radon-Daughter Concentrations Using the Electronic Radon Progeny Integrating Sampling Unit (ERPISU) Method. (M. D. Pearson)

Procedure Manual for the Estimation of Average Indoor Radon-Daughter Concentrations Using the Filtered Alpha-Track Method. (J. L. George)

Detecting Buried Radium Contamination Using Soil-Gas and Surface-Flux Radon Measurements. (K. E. Karp)

Exposure-Rate Calibration Using Large-Area Calibration Pads. (E.F. Novak)

\footnotetext{
Available irom National Technical Information Service, U.S. Department of Commerce, 5285 Port Royal Road, Springfieid, Virginia 22161, (703) 487-4600.
} 


\begin{tabular}{|c|c|c|}
\hline & Number & Title (Authors) \\
\hline & UNC/GJ-43(TMC)* & $\begin{array}{l}\text { Year-Long Comparison of Two Techniques to Monitor Outdoor Radon } \\
\text { Concentrations at Shiprock, New Mexico. (E. F. Novak) }\end{array}$ \\
\hline & UNC/GI-TMC-3* & $\begin{array}{l}\text { Procedures, Analysis, and Comparison of Groundwater Velocity Measurement } \\
\text { Methods for Unconfined Aquifers. (P. M. Kearl, J. J. Dexter, and J. E. Price) }\end{array}$ \\
\hline & UNC/GJ-TMC-4* & $\begin{array}{l}\text { Supplement to Procedures, Analysis, and Comparison of Groundwater Velocity } \\
\text { Measurement Methods for Unconfined Aquifers. (R. J. Zinkl and P. M. Kearl) }\end{array}$ \\
\hline & $\mathrm{UNC} / \mathrm{GJ}-44(\mathrm{TMC})^{*}$ & $\begin{array}{l}\text { Evaluation of the Performance Characteristics of Radon and Radon-Daughter } \\
\text { Concentration Measurement Devices Under Controlled Environmental } \\
\text { Conditions. (M. D. Pearson) }\end{array}$ \\
\hline & $\mathrm{UNC} / \mathrm{GJ}-45(\mathrm{TMC})^{*}$ & $\begin{array}{l}\text { Construction and Characterization of the RH/RL Radium Calibration Pads. } \\
\text { (W. D. Steele, S. J. Marutzky, and J. W. Dickerson) }\end{array}$ \\
\hline & UNC/GJ-46(TMC) & $\begin{array}{l}\text { Performance of Diffusion-Barrier Scintillation Cells Under a Variety of } \\
\text { Controlled Environmental Conditions. (R. R. Spangler and G. H. } \\
\text { Langner, Jr.) }\end{array}$ \\
\hline & $\mathrm{UNC} / \mathrm{GJ}-47(\mathrm{TMC})^{*}$ & $\begin{array}{l}\text { Validation of the Diffusion-Barrier Charcoal Canister Method. (D. E. Martz, } \\
\text { J. L. George, S. T. Mamich, and G. H. Langner, Jr.) }\end{array}$ \\
\hline & UNC/GJ-48(TMC)* & Field Method for Determining Thorium-230 in Soils. (G. Dechant) \\
\hline & UNC/GJ-TMC-5* & $\begin{array}{l}\text { Development of Electret Technology to Measure Indoor Radon-Daughter } \\
\text { Concentrations (Stieff Research and Development Co., Inc., Kensington, } \\
\text { Maryland) }\end{array}$ \\
\hline & $\mathrm{UNC} / \mathrm{GJ}-\mathrm{TMC}-6^{*}$ & $\begin{array}{l}\text { Radon-Daughter Grab-Sampling Technical Exchange Meeting } \\
\text { April 10-14, 1989. (M. D. Pearson) }\end{array}$ \\
\hline & UNC/GJ-49(TMC)* & $\begin{array}{l}\text { Gamma and Beta Logging of Underground Sewer and Process Lines. } \\
\text { (M.J. Rangel, D. E. Martz, and G.H. Langner, Jr.) }\end{array}$ \\
\hline
\end{tabular}

$$
\begin{aligned}
& . \quad \text { Number } \\
& \therefore \quad \text { UNC/GJ-43(TMC)* }
\end{aligned}
$$$$
\text { UNC/GI-TMC-3* }
$$$$
\text { UNC/GJ-TMC-4* }
$$$$
\text { UNC/GI-44(TMC)* }
$$

UNC/GJ-45(TMC)
UNC/GJ-46(TMC)

$\mathrm{UNC} / \mathrm{GJ}-47(\mathrm{TMC})^{*}$
Year-Long Comparison of Two Techniques to Monitor Outdoor Radon Concentrations at Shiprock, New Mexico. (E. F. Novak)

Procedures, Analysis, and Comparison of Groundwater Velocity Measurement Supplement to Procedures, Analysis, and Comparison of Groundwater Velocity Measurement Methods for Unconfined Aquifers. (R. J. Zinkl and P. M. Kearl)

Evaluation of the Performance Characteristics of Radon and Radon-Daughter Concentration Measurement Devices Under Controlled Environmental Conditions. (M. D. Pearson)

Construction and Characterization of the RH/RL Radium Calibration Pads. W. D. Steele, S. J. Marutzky, and J. W. Dickerson)

Performance of Diffusion-Barrier Scintillation Cells Under a Variety of Controlled Environmental Conditions. (R. R. Spangler and G. H.

Validation of the Diffusion-Barrier Charcoal Canister Method. (D. E. Martz, Field Method for Determining Thorium-230 in Soils. (G. Dechant)

Development of Electret Technology to Measure Indoor Radon-Daughter Concentrations (Stieff Research and Development Co., Inc., Kensington,

Radon-Daughter Grab-Sampling Technical Exchange Meeting

Gamma and Beta Logging of Underground Sewer and Process Lines.

(M.). Rangel, D. E. Martz, and G. H. Langner, Jr.)

"Available from National Technical Information Service, U.S. Department of Commerce, 5285 Port Royal Road, Springfield, Virginia 22161, (703) $487-4600$. 